\title{
Unicentric Castleman's Disease: Case Report and Literature Review
}

\author{
Keishla M García and Angel M Rodriguez* \\ Department of Oncology, San Juan Bautista School of Medicine, USA
}

Submission: March 15, 2018; Published: March 23, 2018

"Correspondence Address: Angel M Rodriguez Rivera, Surgical Oncologist, Chair of Surgical Department of San Juan Bautista School of Medicine, Caguas, Puerto Rico, USA, Email: rodriguez@cancerdoctorpr.com

\section{Abstract}

Castleman's disease (CD), also known as giant lymph node hyperplasia or angiofollicular lymph node dysplasia, is a rare benign immunoproliferative disorder. CD is classified by histopathologic appearance (hyaline vascular, plasma cell or mix variant) as well as by the number of lymph nodes that are involved (unicentric and multicentric). We report the case of a 24-year-old female who was found to have unicentric anterior mediastinum CD. This article describes the clinical features, pathogenesis, diagnosis, and current treatment modalities for this uncommon disease.

Keywords: Castleman's disease; Mediastinal mass, Lymph node hyperplasia; IL-6

Abbreviations: CD: Castleman's disease; CT: Computerized Tomography; PET: Positron Emission Tomography

\section{Introduction/Background}

Castleman's disease (CD), also known as giant lymph node hyperplasia or angiofollicular lymph node dysplasia, is a rare benign immunoproliferative disorder initially described in 1954 by Benjamin Castleman et al. [1]. Castleman identified a group of thirteen patients with a solitary mediastinal mass that microscopically showed hyperplastic lymphoid follicles with thick hyalinized walls, a germinal center formation and marked capillary proliferation [1]. This histopathologic variant is known as hyaline vascular type. Subsequently, another histopathological distinction was described by Castleman in 1971, and is known as plasma-cell type [2]. Lastly, a mix type form may also be present.

CD can be further categorized depending upon the number of lymph nodes involved. Unicentric CD describes the involvement of a single lymph node while multicentric CD involves multiple lymph nodes. In the majority of unicentric CD cases, the patient presents with an asymptomatic solitary mass in the mediastinum along the tracheobronchial pulmonary tree or hila [3]. However, there have been reports of lymph nodes found in the intrapulmonary fissures, intercostal spaces, pelvis, neck and retroperitoneum [3]. This category of CD is usually associated with the hyaline-vascular variant, which comprises ninety percent of the cases and is considered benign $[3,4]$.

On the other hand, multicentric CD involves multiple hyperplastic lymph nodes and is usually symptomatic. This type mostly involves a plasma cell type histology, and comprises about ten percent of the cases $[4,5]$. Patients in this group present with generalized systemic symptoms, such as fever, hematologic abnormalities, elevated erythrocyte sedimentation rate, growth retardation, nephrotic syndrome, and the potential involvement of other organs [4].

\section{Case Presentation}

A 24-year-old female presented with nonproductive cough for four weeks. She denied other systemic symptoms. Previous medical history was unremarkable and she was a non-smoker. Family history was contributory for ovarian cancer. Physical examination was unremarkable. Her blood work results were all within normal limits and a Human Immunodeficiency Virus test was negative.

A chest $x$-ray revealed mild left-ward deviation of the trachea and a contrast CT scan was obtained. A solid heterogeneous enhancing mass was found of approximately $3.5 \mathrm{~cm}$ is largest axial diameter localized inferior to the right thyroid lobe and extending into the anterior mediastinum, causing mass effect and left-ward deviation of the trachea (Figure 1). A positron emission tomography (PET)-CT scan was performed, and showed a soft tissue mass in the right neck Level IV compartment that extended into the superior mediastinum (Figure 2). 


\section{Cancer Therapy \& Oncology International Journal}
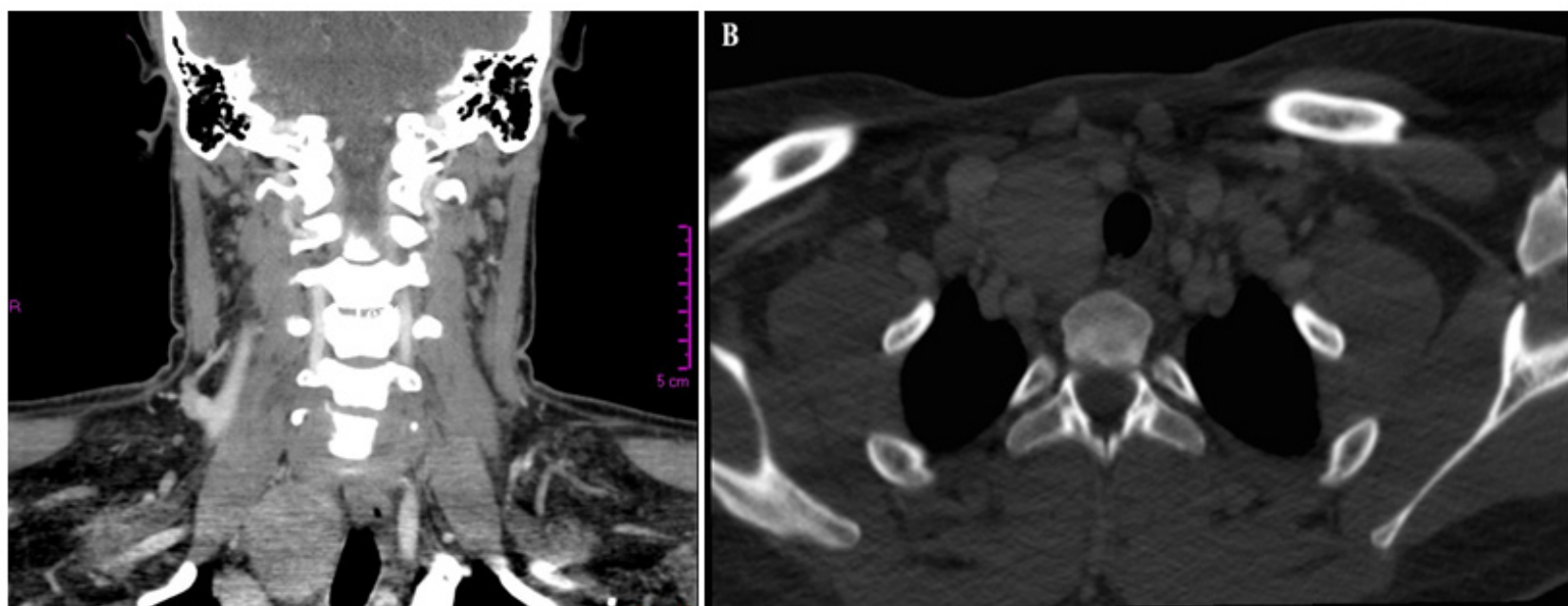

Figure 1: Chest CT scan with evident solid heterogeneous enhancing mass of approximately $3.5 \mathrm{~cm}$ in largest axial diameter localized inferior to the right thyroid lobe extending through the thoracic inlet.

A. Coronal view.

B. Axial (transverse) view.

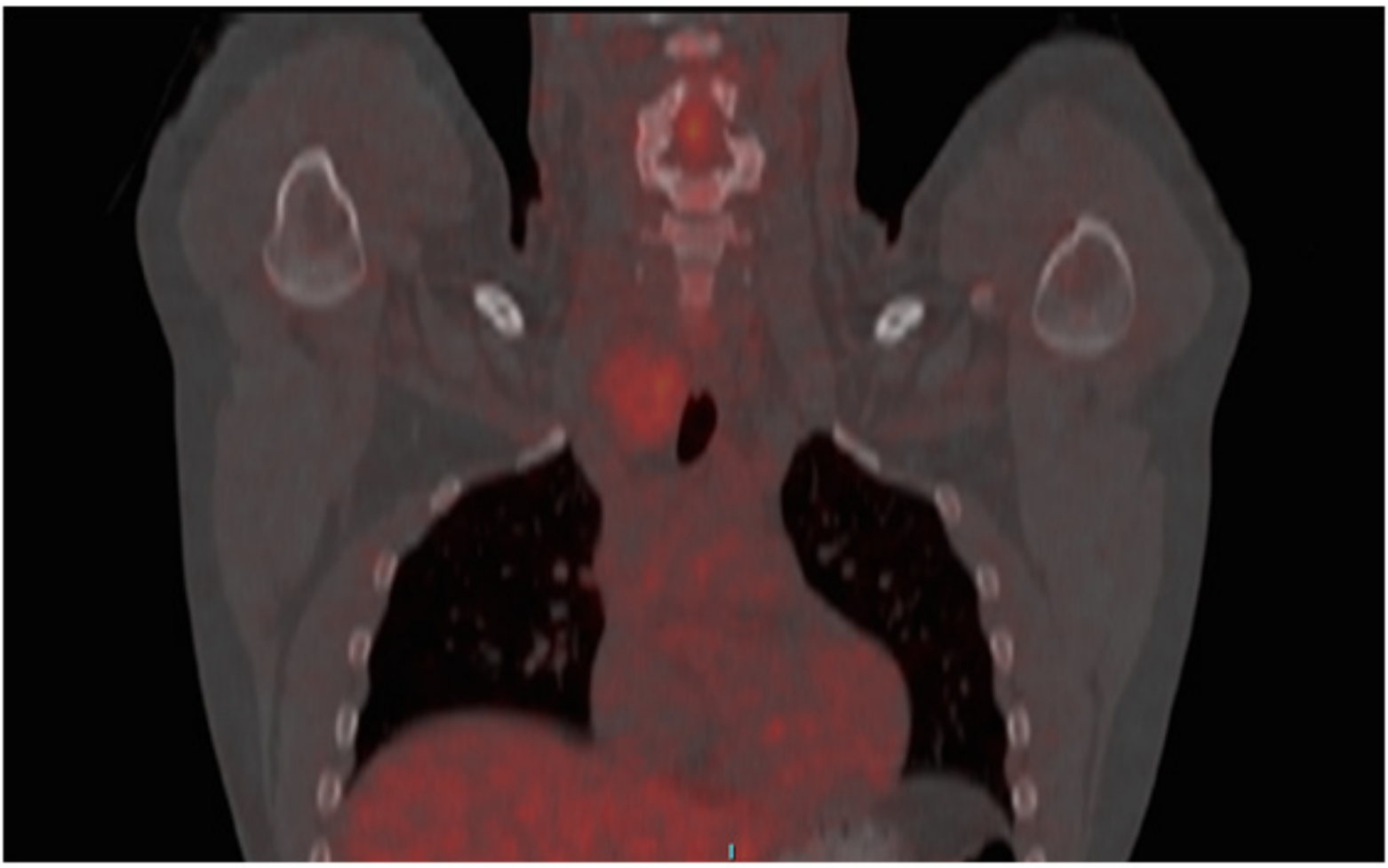

Figure 2: PET-CT scan showing a soft tissue mass in the right neck Level IV compartment.

A subsequent core needle biopsy was performed. This showed lymph node tissue with paracortical hyperplasia, increased vascularity, focal hyalinization, reactive germinal center and groups of follicular dendritic cells. A mediastinal mass with these characteristics, based on histologic and imaging findings, was suggestive of hyaline-vascular Castleman's disease. There was no histopathological evidence of lymphoma on the specimen (flow cytometric studies performed). Subsequently, a complete resection of the mass was performed. Histologic examination confirmed the diagnosis of Castleman's disease, 


\section{Cancer Therapy \& Oncology International Journal}

hyaline vascular type. Six months after surgery, the patient remains asymptomatic and no other lymph node enlargement has been detected. A CT follow-up was performed and there were no abnormal findings.

\section{Discussion}

The etiology of CD is still unclear. Theories such as inflammatory origin, hyperplasia of hamartomatous lymphoid tissue or inappropriate immune response have been proposed $[3,6]$. CD has also been associated with human immunodeficiency virus and human herpes virus [6-8]. The differential diagnoses of a mediastinal mass include: thymoma, lymphoma, teratoma or unicentric CD. Normally, the former three would not show enhancement in a contrast CT scan [3]. In the case of unicentric $\mathrm{CD}$, post-contrastenhancement is seen due to its hypervascularity [3]. A PET scan can be used to determine if there is any other lymph nodes involved [8]. To confirm the diagnosis, a core needle or open biopsy should be performed. This will show a polyclonal nodal expansion with the histologic features of one of the variants mentioned previously.
Diverse types of management have been proposed (Tables 1 \& 2). Surgical resection is considered curative in the vast majority of cases 4 (Table 1) Bowne et al. [5]. A recent systematic review of 278 cases of unicentric $C D$ showed that the outcomes for complete resection (R0) of the tumor were significantly better than for an incomplete resection $[8,9]$. Chronowski et al. [10], reported that radiotherapy has the ability to achieve complete radiographic and clinical resolution on unicentric CD in a selected group of patients, but the rates of disease free survival for surgical resection were still higher Bowne et al. [5] (Table 2). For this reason, radiotherapy should be considered for a poor surgical candidate or for unresectable unicentric CD. A study by Yoshizaki et al. [7] demonstrated that, in fact, the cells present in the germinal centers of the hyperplastic lymph nodes produce IL- 6 and found a correlation of this production with the serum levels of IL-67 Abdessayed et al. [13]. Thus, another treatment modality that has been proposed is the blockage of the IL-6 dysregulated overproduction $[7,11]$, especially in patients with plasma-cell variant [11] \& Ren et al. [14].

Table 1: Review of literature about Unicentric Castleman's Disease treated with complete surgical resection.

\begin{tabular}{|c|c|c|c|c|c|}
\hline Study & Age & Sex & Year & Location & Clinical Response \\
\hline \multirow[t]{10}{*}{ Bowne et al. [5] } & 47 & $\mathrm{~F}$ & 1999 & Chest wall & NED at $10 \mathrm{mo}$ \\
\hline & 32 & $\mathrm{~F}$ & 1999 & Retroperitoneum & NED at $13 \mathrm{mo}$ \\
\hline & 46 & $\mathrm{~F}$ & 1999 & Axilla & NED at 2 years \\
\hline & 22 & $\mathrm{~F}$ & 1999 & Retroperitoneum & NED at 2 years \\
\hline & 21 & $\mathrm{~F}$ & 1999 & Mediastinum & NED at 1 year \\
\hline & 53 & $\mathrm{~F}$ & 1999 & Retroperitoneum & $\mathrm{NED}$ at $37 \mathrm{mo}$ \\
\hline & 26 & M & 1999 & Mediastinum & NED at 2 years \\
\hline & 33 & $\mathrm{~F}$ & 1999 & Mesentery & NED at 1 year \\
\hline & 29 & $\mathrm{~F}$ & 1999 & Mesentery & $\mathrm{NED}$ at $25 \mathrm{mo}$ \\
\hline & 45 & $\mathrm{~F}$ & 1999 & Mediastinum & NED at $10 \mathrm{mo}$ \\
\hline \multirow[t]{6}{*}{ Chronowski et al. [10] } & 45 & $\mathrm{~F}$ & 2001 & Cervical & NED at $4 \mathrm{mo}$ \\
\hline & 21 & M & 2001 & Hilum & NED at $62 \mathrm{mo}$ \\
\hline & 26 & M & 2001 & Cervical & NED at $32 \mathrm{mo}$ \\
\hline & 51 & M & 2001 & Cervical & NED at $40 \mathrm{mo}$ \\
\hline & 15 & $\mathrm{~F}$ & 2001 & Axilla & NED at 74 mo \\
\hline & 41 & M & 2001 & Axilla & NED at $26 \mathrm{mo}$ \\
\hline Haro et al. [12] & 77 & $\mathrm{~F}$ & 2016 & Mediastinum & Asymptomatic \\
\hline Abdessayed et al. [13] & 34 & $\mathrm{~F}$ & 2017 & Retroperitoneum & $\mathrm{NED}$ at $12 \mathrm{mo}$ \\
\hline Ren et al. [14] & 35 & $\mathrm{~F}$ & 2018 & Mediastinum & $\begin{array}{c}\text { Recurrence after } 14 \\
\text { years }\end{array}$ \\
\hline
\end{tabular}

F: Female; M: Male; NED: No evidence of disease; Mo: Months. 


\section{Cancer Therapy \& Oncology International Journal}

Table 2: Review of literature about Unicentric Castleman's Disease treated with Radiotherapy.

\begin{tabular}{|c|c|c|c|c|c|}
\hline Study & Age & Sex & Year & Location & Clinical Response \\
\hline Nordstrom et al. [15] & 50 & $\mathrm{~F}$ & 1978 & Mesenteric & NED at 8 mo \\
\hline Weisenburger et al. [16] & 51 & $\mathrm{~F}$ & 1979 & Mesenteric & $\begin{array}{l}\text { Decrease in size at } 6 \mathrm{mo} \text {, } \\
\text { then regrowth at } 10 \mathrm{mo}\end{array}$ \\
\hline Stokes et al. [4] & 45 & M & 1985 & Paraspinal & $\begin{array}{l}\text { Asymtomatic and no } \\
\text { lymphadenopathy at } 5 \\
\text { years }\end{array}$ \\
\hline Sethi et al. [17] & 25 & M & 1990 & Submandibular & NED at $22 \mathrm{mo}$ \\
\hline Veldhuis et al. [18] & 62 & $\mathrm{~F}$ & 1996 & Supraclavicular & NED after 2 years \\
\hline \multirow[t]{4}{*}{ Chronowski et al. [10] } & 38 & $\mathrm{~F}$ & 2001 & Retroperitoneum & Complete response \\
\hline & 24 & $\mathrm{~F}$ & 2001 & Mediastinum & $\begin{array}{l}\text { Asymptomatic; decrease } \\
\text { in tumor size }\end{array}$ \\
\hline & 37 & M & 2001 & Mediastinum & Complete response \\
\hline & 51 & $\mathrm{~F}$ & 2001 & Axilla & Complete response \\
\hline \multirow[t]{3}{*}{ Neuhof et al. [19] } & 24 & $\mathrm{~F}$ & 2006 & Mediastinal & Decrease size at $12 \mathrm{mo}$ \\
\hline & 71 & M & 2006 & Mediastinal & $\begin{array}{c}\text { Progressive disease after } \\
\text { 3mo }\end{array}$ \\
\hline & 38 & $\mathrm{~F}$ & 2006 & Cervical & $\begin{array}{l}\text { Complete remission after } \\
4 \mathrm{mo}\end{array}$ \\
\hline \multirow[t]{2}{*}{ Noh et al. [20] } & 20 & $\mathrm{~F}$ & 2013 & Supraclavicular & Decrease in size at $14 \mathrm{mo}$ \\
\hline & 56 & $\mathrm{~F}$ & 2013 & Para-aortic & NED after 12 months \\
\hline
\end{tabular}

F: Female; M: Male; NED: No evidence of disease; Mo: Months.

Although unicentric CD is considered a benign condition, surgical resection is highly recommended because of mass effect on adjacent structures Nordstrom et al. [15]. A secondary consideration for surgery is that it may have malignant potential [6]. This neoplastic potential is higher with the plasma-cell variant [3]. In the case of multicentric CD, surgery does not have offer curative intent and the treatment focuses on symptom relief and clinical findings of each patient [9]. A study performed by The American Society of Hematology used a humanized anti IL-6 receptor antibody to treat patients with multicentric plasma cell or mixed type CD. After the administration of this antibody Weisenburger et al. [16], a clinical response was achieved [1114]. Also, when histopathological examination was performed, pathological response was noted with a reduction of follicular hyperplasia and vascularity [15-18].

$\mathrm{CD}$ is an uncommon and poorly understood disease that warrants more investigation Stokes et al. [4], Sethi et al. [17], Chronowski et al. [10], Neuhof et al. [19], Noh et al. [20]. Further studies are required to identify an etiology and describe the epidemiology of CD $[19,20]$. Due to its low incidence, there have been no randomized clinical trials, and all the available data comes from systematic reviews, case series and case reports [8].

\section{Acknowledgement}

We thank the patient for allowing us to share her details.

\section{Conflict of Interest}

The authors declare that there is no conflict of interest

\section{References}

1. Castleman B, Iverson L, Menendez VP (1997) Localized mediastinal lymph-node hyperplasia resembling thymoma. Cancer 9(4): 822-830.

2. Keller AR, Hochholzer L, Castleman B (1972) Hyaline-vascular and plasma-cell types of giant lymph node hyperplasia of the mediastinum and other locations. Cancer 29: 670-683.

3. Kim JH, Jun TG, Sung SW, Shim YS, Han SK, et al. (1995) Giant lymph node hyperplasia (Castleman's disease) in the chest. Ann Thorac Surg 59(5): 1162-1165.

4. Stokes SH, Griffith RC, Thomas PR (1985) Angiofollicular lymph node hyperplasia (Castleman's disease) associated with vertebral destruction. Cancer 56(4): 876-879. 


\section{Cancer Therapy \& Oncology International Journal}

5. Bowne WB, Lewis JJ, Filippa DA, Filippa DA, Ruben Niesvizky, et al (1999) The management of unicentric and multicentric Castleman's disease: a report of 16 cases and a review of the literature. Cancer 85 : 706-717.

6. Ko SF, Ng SH, Hsieh MJ, Lin JW, Huang CC, et al. (2003) Castleman disease of the pleura: experience with eight surgically proven cases. Ann Thorac Surg 76(1): 219-224.

7. Yoshizaki K, Matsuda T, Nishimoto N, Kuritani T, Taeho L, et al. (1989) Pathogenic significance of interleukin-6 (IL-6/BSF-2) in Castleman's disease. Blood 74(4): 1360-1367

8. Brown JR, Aster JC, Munshi NC (2017) Unicentric Castleman's Disease. Genetic and Rare Diseases Information Center (GARD), Gaithersburg, Maryland, USA.

9. Talat N, Belgaumkar AP, Schulte KM (2012) Surgery in Castleman's disease: a systematic review of 404 published cases. Ann Surg 255: 677-684.

10. Chronowski GM, Ha CS, Wilder RB, Cabanillas F, Manning J, et al. (2001) Treatment of unicentric and multicentric Castleman disease and the role of radiotherapy. Cancer 92(3): 670-676.

11. Nishimoto N, Sasai M, Shima Y, Nakagawa M, Tomoshige Matsumoto, et al. (2000) Improvement in Castleman's disease by humanized antiinterleukin-6 receptor antibody therapy. Blood 95: 56-61.

12. Haro A, Kuramitsu E, Fukuyama Y (2016) Complete resection of unicentric Castleman disease in the superior mediastinum: A case report. Int J Surg Case Rep 25: 44-47.
13. Abdessayed N,Bdioui A,Ammar H, Gupta R, et al. (2017) Retroperitoneal unicentric Castleman's disease: A case report. Int J Case Rep 31: 54-57.

14. Ren N, Ding L, Jia E, Xue J (2018) Recurrence in unicentric castleman's disease postoperatively: a case report and literature review. BMC Surg 18: 1.

15. Nordstrom DG, Tewfik HH, Latourette HB (1978) Giant lymph node hyperplasia: a review of literature and report of two cases of plasma cell variant responding to radiation therapy. Int J Radiat Oncol Biol Phys 4(11-12): 1045-1048.

16. Weisenburger DD, DeGowin RL, Gibson P, Armitage JO (1979) Remission of giant lymph node hyperplasia with anemia after radiotherapy. Cancer 44(2): 457-462.

17. Sethi T, Joshi K, Sharma SC, Gupta BD.(1990) Radiation therapy in the management of giant lymph node hyperplasia. Br J Radiol 63: 648-650.

18. Veldhuis GJ, van der Leest AHD, de Wolf JTM, de Vries EGE, Vellenga E (1996) A case of localized Castleman's disease with systemic involvement: treatment and pathogenetic aspects. Ann Hematol 73(1): 47-50.

19. Neuhof D, Debus J (2006) Outcome and late complications of radiotherapy in patients with unicentric Castleman disease. Acta Oncol 45(8): 1126-1131.

20. Noh OK, Lee S, Lee JW, Kim SY, Kim CS, et al. (2013) Cases report of unicentric castleman's disease: revisit of radiotherapy role. Radiat Oncol J 31(1): 48-54. 